\title{
PERLINDUNGAN HUKUM TERHADAP EKSISTENSI MASYARAKAT ADAT DI INDONESIA
}

\author{
Besse Sugiswati \\ Fakultas Hukum Universitas Wijaya Kusuma Surabaya \\ e-mail: kietaw53@yahoo.com
}

\begin{abstract}
ABSTRAK
Keberadaan masyarakat adat dalam Undang-Undang Dasar 1495 hasil amandemen mendapat pengakuan dan penghormatan, termaktub dalam Pasal 18B ayat 2. Pasal ini memberikan posisi konstitusional kepada masyarakat adat dalam hubungannya dengan negara, bagaimana komunitas diberlakukan. Kehadiran masyarakat adat merupakan suatu kenyataan sejarah yang tidak dapat dihindari atau disangkal oleh pemerintah. Pemerintah Daerah diberi kewenangan regulasi untuk penentuan keberadaan suatu masyarakat hukum adat yang masih hidup di tingkat kabupaten dan kota tanpa rambu-rambu yang jelas. Hal ini dapat menimbulkan konflik, baik antar daerah maupun antar pemerintah daerah dengan masyarakat hukum tertentu. Sejak era reformasi, masyarakat hukum adat seluruh Indonesia banyak melakukan penuntutan-penuntutan kembali hak mereka yang dirampas secara paksa atau dengan cara lain, baik oleh pemerintah maupun kelompok orang tertentu.
\end{abstract}

Kata kunci: keberadaan masyarakat adat, konflik, pengakuan hak.

\begin{abstract}
The existence of tribute people on the Constitution of 1945, the result of amendment has acknowledged and appreciated in chapter $18 \mathrm{~B}$ verses 2. This chapter gives position of constitution to tribute people dealing with state, how they are performed. The coming of tribute people is a fact that history can be avoided by government. The regional government is given the authorization to make rules clearly. It can raise conflict either for between regional or regional government with certain law society. Since reformation, law of civil society in Indonesia demands much their rights which are stolen by government or other certain groups.
\end{abstract}

Keywords: existence of tribute people, conflict, right acknowledgement.

\section{PENDAHULUAN}

Indonesia disebut Nusantara karena terdiri ribuan pulau ( \pm 13.487 pulau) dan disebut sebagai negara kepulauan terbesar di dunia. Dari kota Sabang sampai kota Merauke, Indonesia terdiri dari berbagai suku, bahasa, agama yang berbeda, dan memiliki semboyan Bhinneka Tunggal Ika. Selain memiliki populasi padat dan wilayah yang luas, Indonesia memiliki wilayah alam yang mendukung tingkat keanekaragaman hayati terbesar kedua di dunia.

Di dalam setiap adat, bahasa, suku dan agama itu, terkandung sistem nilai dan sistem pengetahuan yang sudah bertumbuh ratusan bahkan ribuan tahun yang lalu. Negeri kita diatur dan dikelola secara turuntemurun dengan ribuan hukum adat, dipandu oleh ratusan sistem kepercayaan dan agama. Indonesia adalah bangsa yang dibangun dari ratusan atau bahkan ribuan bangsa-bangsa yang berdaulat, mandiri dan bermartabat, yang dalam sejarahnya masing-masing mengalami pasang surut. Ribuan hukum adat ini merupakan konsekwensi dari beragam suku bangsa di berbagai daerah di Indonesia.

Indonesia adalah negara bahari yang terhubung oleh lautan yang luas. Selain terdiri dari ribuan hukum adat, konsekwensi negeri bahari ini juga merupakan tantangan besar bagi kita untuk tetap berkomitmen dalam hidup berbangsa dan bernegara. Konsekwensi dari keanekaragaman hukum adat dan kebaharian negara kita mengancam kepunahan berbagai bahasa suku, hilangnya hukum adat, kaburnya berbagai identitas budaya dari tengah masyarakat, dan lemahnya otoritas lembaga adat dalam kehidupan kebangsaan dan kenegaraan. Lebih memprihatinkan lagi, sampai saat ini masih berlangsungnya pengambilalihan secara sepihak dan perampasan atas tanah adat, air adat, wilayah adat dan sumberdaya alam lainnya, yang oleh leluhurnya dititipkan kepada masyarakat adat.

Hukum adat merupakan hukum yang bersumber pada ugeran-ugeran atau norma-norma kehidupan sehari-hari yang langsung timbul sebagai pernyataan 
kebudayaan orang Indonesia asli dalam hal ini sebagai pernyataan rasa keadilan dalam hubungan pamrih, sehingga jelas disini bahwa hukum adat di wilayah Negara Kesatuan Republik Indonesia adalah hukum asli Indonesia yang dibuat oleh masyarakat Indonesia secara turun temurun berdasarkan value consciousness mereka yang termanifestasi dalam kebiasaan hidup sehari-hari dengan menggunakan ukuran nalar dan rasa keadilan mereka. Dengan demikian jika kembali pada pemikiran Von Savigny bahwa hukum adalah cerminan jiwa rakyat, maka hukum adatlah yang merupakan jiwa bangsa Indonesia (Djojodigoeno dalam Soerojo Wignjodipuro, 1979:64).

Masyarakat hukum adat merupakan suatu satu kesatuan masyarakat dalam satu wilayah adat yang bersifat otonom, dimana mereka mengatur sistem kehidupannya secara mandiri (antara lain: hukum, politik, ekonomi, dan sebagainya) dan juga bersifat otonom, yaitu suatu kesatuan masyarakat adat yang lahir atau dibentuk oleh masyarakat itu sendiri, bukan dibentuk oleh kekuatan lain, misal kesatuan desa dengan Lembaga Ketahanan Masyarakat Desanya. Kehidupan komunitas masyarakat adat kini tidak sepenuhnya bersifat otonom dan terlepas dari proses integrasi ke dalam kesatuan organisasi kehidupan negara bangsa yang berskala besar dan berformat nasional. Sehingga rumusan mengenai masyarakat adat yang dibuat pada masa sebelum kemerdekaan cenderung bersifat kaku dalam kondisi masyarakat adat yang statis tanpa tekanan perubahan, sedangkan rumusan tentang masyarakat adat yang dibuat setelah kemerdekaan lebih bersifat dinamis melihat kenyataan masyarakat adat saat ini dalam tekanan perubahan (Martua Sirait, dkk., No. 24 hal. 5).

Maria S.W. Sumardjono mengartikan masyarakat hukum adat sebagai masyarakat yang timbul secara spontan di wilayah tertentu dengan rasa solidaritas yang besar di antara anggotanya dan memandang yang bukan anggota sebagai orang luar, menggunakan wilayahnya sebagai sumber kekayaan yang hanya dapat dimanfaatkan sepenuhnya oleh anggotanya, pemanfaatan oleh orang luar harus dengan izin dan pemberian imbalan tertentu berupa recognisi (Abrar Saleng, 2004:51).

Dalam literatur dan peraturan perundang-undangan terdapat dua penyebutan istilah masyarakat adat, yaitu ada yang menyebutnya masyarakat adat dan ada juga yang menyebut masyarakat hukum adat. Walaupun demikian, perbedaan peristilahan tersebut tidak menafikan atau menegaskan hak-hak adat yang dimiliki oleh masyarakat yang bersangkutan (Lisman Sumardjani, 2007:1).
International Labour Organization (selanjutnya disebut ILO) mengeluarkan Konvensi ILO No. 169 Tahun 1989, yang merumuskan masyarakat adat sebagai masyarakat yang berdiam di negara-negara yang merdeka dimana kondisi sosial, kultural dan ekonominya membedakan mereka dari bagian-bagian masyarakat lain di negara tersebut, dan statusnya diatur, baik seluruhnya maupun sebagian oleh adat dan tradisi masyarakat adat tersebut atau dengan hukum dan peraturan khusus (Abrar Saleng, 2004:4).

Istilah masyarakat adat mulai mendunia, setelah pada tahun 1950-an ILO, sebuah badan dunia di Perserikatan Bangsa-Bangsa (yang selanjutnya akan disebut (PBB) mempopulerkan isu indigenous peoples atau masyarakat adat. Setelah dihembuskan oleh ILO sebagai isu global di lembaga PBB, World Bank juga mengadopsi isu tersebut untuk proyek pendanaan pembangunan di sejumlah negara, melalui kebijakan OMP (1982) dan OD (1991), terutama di negaranegara ketiga, seperti di Amerika Latin, Afrika, dan Asia Pasifik. Mencuatnya isu masyarakat adat berawal dari berbagai gerakan protes masyarakat asli (native peoples) di Amerika Utara yang meminta keadilan pembangunan, setelah kehadiran sejumlah perusahaan transnasional di bidang pertambangan beroperasi di wilayah kelola mereka, dan pengembangan sejumlah wilayah konservasi oleh pemerintah AS dan Kanada (Azmi Siradjudin A.R., 2010:1).

Komunitas Inuit di Alaska adalah korban dari ketidakadilan pembangunan industri pertambangan di Amerika Serikat. Di Kanada, komunitas Inuit yang masuk dalam wilayah negara tersebut juga memprotes kebijakan pemerintah Kanada yang memaksa mereka harus meninggalkan wilayah kelola menuju desa-desa di pinggir kota, karena perusahaan migas dan batubara akan mengelola wilayah tersebut. Di sebelah tengah Amerika Serikat, pembangunan Taman Nasional Missisipi juga menghilangkan hak kelola komunitas pribumi Indian lainnya, seperti Mohak. Sedangkan pembangunan Taman Nasional Rocky Mountain di sebelah barat juga mengancam kehidupan Indian Apache. Berbagai protes dari native peoples di dataran Amerika Utara di tahun 1950-an, memancing reaksi ILO sebagai lembaga PBB yang bergerak dalam isu perlindungan tenaga kerja. Oleh karena itu, ILO kemudian melakukan berbagai riset lapangan, dan pada tahun 1957 ILO mengeluarkan Konvensi No. 107 dan Rekomendasi No. 104 tentang Perlindungan dan Integrasi Penduduk Asli dan Masyarakat Suku. Pada tahun 1989, Konvensi tersebut diperbaharui oleh ILO dengan Konvensi No. 169 (Azmi Siradjudin A. R., 2010:1). 
Isu-isu ketidakadilan yang dirasakan oleh berbagai komunitas indie ataupun native peoples berpengaruh bagi ILO untuk memunculkan isu generatifnya, yaitu indigenous peoples. Oleh gerakan Ornop (organisasi non-pemerintah) di Indonesia, kemudian di adopsi dan diterjemahkan menjadi kosakata masyarakat adat, terutama pada pertemuan bertajuk Lokakarya Pengembangan Sumberdaya Hukum Masyarakat Adat tentang Pengelolaan Sumberdaya Alam di dalam Kawasan Hutan, yang berlangsung pada tanggal 25 sampai dengan 29 Mei 1993, di Toraja, Sulawesi Selatan. Isu masyarakat adat semakin memperoleh tempatnya dalam gerakan masyarakat sipil melalui pendeklarasian pembentukan Aliansi Masyarakat Adat Nusantara (AMAN) pada tahun 1999 di Jakarta (Azmi Siradjudin A.R., 2010:1).

\section{PEMBAHASAN}

Sejak era reformasi bergulir, masyarakat hukum adat seluruh Indonesia banyak melakukan penuntutanpenuntutan kembali hak mereka yang dirampas secara paksa atau dengan cara lain, baik oleh pemerintah maupun kelompok orang tertentu. Gerakan melakukan penuntutan hak ini sering diwarnai dengan adanya konflik horizontal maupun vertikal (Perpatih Nan Tua, 2006:3).

Beberapa contoh kasus konflik di dalam kawasan hutan pada fungsi hutan dan areal yang berbeda-beda antara lain: Konflik Masyarakat Adat Moronene, Sulawesi Tenggara dengan Pengelola Taman Nasional Rawa Opa Watumohai pada Kawasan Konservasi (Bediona dkk, draft 1999).

Dalam sejarah Sulawesi Tenggara, masyarakat adat Moronene merupakan suku asli tertua yang mendiami daratan Sulawesi Tenggara, di samping orang Tolaki dan Mekongga. Masyarakat adat Moronene menyebar hingga 6 kecamatan. Masyarakat adat Moronene di Kecamatan Rumbia terbagi atas 11 tobu (wilayah adat). Kepemimpinan lembaga adat dikenal dengan sebutan Mokole. Mereka telah mengelola wilayah leluhurnya di HukaEka, Lampopala dan sekitarnya sejak tahun 1920-an. Selain perkampungan lahan digunakan untuk kebun, lahan pengembalaan kerbau dan kuda, kebun jati, tambak bersama pada muara-muara sungai, kuburan dan lain-lain. Pada tahun 1952, 1953 serta tahun 1960 mereka terpaksa mengungsi meninggalkan tanah leluhurnya karena gangguan keamanan oleh gerombolan dan kini mereka tinggal berpencar pada kampung-kampung sekitarnya setelah beberapa kali dikumpulkan dan dipindahkan.

Akses masyarakat adat tersebut atas kebun dan usaha tani serta padang pengembalaan telah mulai dibatasi dengan ditetapkannya sebagai Taman Buru pada tahun1972. Pada tahun 1980 wilayah tersebut menjadi calon Taman Nasional, kemudian pada tahun 1990 ditunjuk sebagai Taman Nasional Rawa Opa Watumohai. Proses pengambilalihan lahan di dalam kawasan hutan tersebut berlangsung tanpa melalui proses musyawarah.

Perjuangan masyarakat adat untuk mendapatkan pengakuan atas hak-hak adatnya dilakukan sejak tahun 1987 dengan menulis surat secara berulangulang kepada Wakil Presiden RI serta Pimpro TN. Kesepakatan lisan dengan Tim Gabungan Pemda TK II yang diketuai oleh KakanSospol tanggal 16 Desember 1997 disepakati, bahwa masyarakat tetap tinggal di kampungnya dan memanfaatkan hasil kebun dan hutan sebagaimana biasanya sambil menunggu pembicaraan dengan pimpinan.

Usaha-usaha negosiasi damai yang diprakarsai oleh masyarakat adat dalam mempertahankan hak adatnya justru menimbulkan intimidasi, pengusiran, penyerbuan, penangkapan disertai tembakan beruntun dan pembakaran kampung serta kebun mereka di HukaEna dan Lampopala secara berulang-ulang (30 Maret 1998 dan 23 Oktober 1998) 12 hari setelah kesepakatan lisan tersebut dilakukan.

Penahanan terhadap 12 masyarakat adat dilakukan tanpa adanya penjelasan tentang status serta alasan penahanannya dan tanpa proses hukum yang jelas. Penahanan tidak diikuti dengan proses penyidikan yang jelas sampai berminggu-minggu. Ke-12 tahanan telah mendekam berbulan-bulan di dalam tahanan Polres Buton sampai dengan persidangan tanggal 27 April 1999, masih berstatus tahanan, terpisah jauh dari keluarga dan kerabatnya yang tinggal terpencar dalam suasana ketakutan dan tidak menentu di Taman Nasional Rawa Opa Watumohai. Konflik ini bagi Masyarakat Adat Moronene semakin memperparah keadaan ekonominya dan juga mengembalikan trauma yang telah mereka alami secara berulang ulang pada tahun 1952, 1953, 1960, dan 1998.

Kasus ini merupakan salah satu contoh kasus tentang bagaimana cara pandang birokrasi pemerintah terhadap masyarakat adat yang tinggal di dalam dan sekitar hutan berkenaan dengan pengelolaan kawasan konservasi, dan menunjukkan bahwa masyarakat adat masih dilihat sebagi ancaman terhadap kelestarian kawasan dan ditindak seakan akan mereka bukan sesama manusia.

Konflik pada masyarakat adat Dayak Simpang, di Kalimantan Barat pada Hutan Produksi Terbatas. Masyarakat adat Simpang yang kini bermukim di wilayah Desa Semandang Kiri, Kecamatan Simpang 
Hulu, Kabupaten Ketapang, Propinsi Kalimantan Barat diperkirakan mengelola hutan sejak abad ke 16-17. Tempat tinggal mereka tersebar dalam beberapa kampung yang dikenal wilayahnya sebagai umang desa sembilan domong sapuluh atau disebut juga Kawasan Adat Banua Simpakng atau Tonah Simpang Sakayok. Batas antar Banua dikenal dengan nama Sapat Banua atau kesepakatan batas benua yang dihormati sebagai batas wilayah kewenangan adat masing-masing Banua. Kelembagaan adat di dalam Banua terdiri dari seorang Patinggi, beberapa orang Pateh dan Tamogokng untuk tiap-tiap kampung. Pola pengelolaan Sumber Daya Hutan telah dilakukan secara turun-temurun dengan cara menggolongkan pola-pola penggunaan lahan sebagai berikut: Rima makong utatn torutn yaitu sebagai hutan cadangan, Bawas belukar lako uma sebagai tanah pertanian, Kampbokng temawakng buah janah sebagai kebun buah dan kayu-kayuan, Tonah colap torutn pusaka sebagai wilayah keramat, Kampokng loboh sebagai wilayah pemukiman, dan Are sunge sebagai wilayah sungai untuk tambak dan tempat menjala. Selain wilayah adat, kelembagan adat serta pola pengelolaan sumber daya hutan tersebut, masyarakat adat ini terikat atas suatu hubungan kekerabatan dan adat istiadat yang sama.

Konflik masyarakat adat Simpang ini berbentuk tumpang tindih peruntukan lahan dan pemberian ijin usaha bagi perusahaan atas wilayah adatnya. Berdasarkan pemetaan partisipatif yang dilakukan, terlihat bahwa di wilayah masyarakat adat tersebut terdiri atas 8.894 ha hutan cadangan, 2.848 ha tanah pertanian, 11.200 ha kebun campuran, 81 ha wilayah pemukiman (total $23.023 \mathrm{Ha}$ ), setengah dari lahan itu menurut RTRWP-Kalbar 2008 menjadi Kawasan Budidaya nonKehutanan sedangkan sebagian lagi menjadi Kawasan Budidaya Kehutanan (HPT pada TGHK 1982). Lebih dari itu, wilayah tersebut telah dikeluarkan Surat Keputusan Menteri Kehutanan pada tahun 1997 diberikan bagi beberapa Perusahaan Kehutanan (HPH PT Inhutani II, HPHTI TTJ, PT GDB) dan Perkebunan (P PMK, BSP II, dan PT KOI). Sehingga tidak ada lagi kepastian serta jaminan bagi masyarakat adat atas hak-hak adatnya (wewenang atas wilayah, kelembagaan serta pola pengelolaan sumber daya alam) yang telah dilakukan secara turuntemurun (Kanyan 1999 draft III) (Martua Sirait, dkk, hal 17).

Terlihat kurang adanya visi perlindungan dan pemajuan bagi masyarakat adat dalam perencanaan hutan yang seharusnya melibatkan masyarakat dalam tahap awal perencanan wilayah secara umum dan perencanaan hutan khususnya. Konflik yang menuju pada tindak kekerasan dapat setiap saat terjadi pada wilayah tersebut dan menciptakan kerawanan.

Konflik yang terjadi di masyarakat adat Peminggir, Lampung, atas pengelolaan Hutan Lindung. Sejak sekitar seabad yang lalu masyarakat adat Peminggir atau Pesisir Krui membangun Repong Damar. Dimulai dari pembukaan hutan, berladang (padi dan sayuran), berkebun (kopi, lada), lalu membentuk agroforest (kebun-hutan) yang didominasi oleh pohon damar (shorea javanica) selain buah, kayu dan tumbuhan bermanfat lainnya. Keseluruhan repong Damar di pesisir Krui mencapai 50-an ribu hektar. Wilayah di masyarakat adat Peminggir berbatasan langsung dengan Samudra Hindia di sebelah barat dan Taman Nasional Bukit Barisan Selatan di sebelah timur (dulu Cagar Alam Ratu Wilhemina). Pada zaman Belanda tanah adat diakui sebagai tanah marga dari 16 Marga yang memiliki wewenang disana. Batas Bochwessen (BW, Kawasan hutan) dan tanah Marga dihormati oleh pihak pemerintah Belanda maupun masyarakat sekitarnya.

Pada tahun 1991 Menteri Kehutanan menunjuk TGHK Propinsi Lampung, dimana sebagian dari tanah marga tersebut menjadi kawasan hutan yang terdiri dengan fungsi Produksi Terbatas dan Lindung. Selanjutnya memberikan hak pengusahaan hutan kepada HPH PT BL dan kemudian dialihkan kepada PT Inh V. Perubahan status tanah marga tersebut baru diketahui masyarakat pada tahun 1994 pada saat penataan batas mulai dilakukan. Sejak itu masyarakat adat di Pesisir Selatan mulai dilarang melakukan pengelolaan repong damar di dalam wilayah yang diklaim sebagai kawasan hutan negara. Penolakan masyarakat adat terhadap status kawasan hutan negara dilakukan melalui penolakan wilayahnya dimasuki petugas penataan batas, surat petisi dan delegasi yang dikirim ke Pemerintah Daerah serta Dephut. Jawaban pemerintah atas surat dan petisi masyarakat adat adalah dengan menerbitkan SK Menhut No. 47/Kpts-II/1998 yang menunjuk 29.000 ha repong di dalam kawasan hutan negara sebagai kawasan dengan tujuan istimewa (KDTI), SK ini memberi hak pengusahaan kawasan hutan negara yang terdiri atas HPT dan HL kepada masyarakat adat.

Bentuk yang diharapkan masyarakat adat adalah bukan pemberian hak pengusahaan repong damar yang dapat dicabut sewaktu waktu dan masih kuatnya intervensi pengaturan oleh Departemen Kehutanan dan Perkebunan tetapi suatu bentuk hak atas dasar pengakuan keberadaan masyarakat adat, wilayah adatnya serta pola pengelolaanya kebun damarnya 
sebagai suatu usaha pertanian. Masyarakat adat Krui tengah mempersiapkan pendekatan litigasi untuk mendapatkan kembali hak kepemilikan tanahnya atas usaha tani kebun damarnya.

Walaupun pemberian hak pengusahaan belum memenuhi harapan masyarakat adat Krui akan tetapi SK ini menunjukan pengakuan atas pola pengelolaan sumber daya hutan oleh masyarakat adat dalam bentuk aslinya (Repong Damar) dan jaminan bahwa pola tersebut dapat dilanjutkan (Kusworo dalam BSP, 1999) (Martua Sirait, dkk, hal 20).

Konflik yang terjadi antara masyarakat Mesuji dengan PT. Silva Inhutani. Pada masa Orde Baru, terutama di sekitar tahun 1980-1997, pemerintah banyak memberikan izin-izin lokasi dan pengusahaan hutan kepada perusahaan-perusahaan yang bergerak di bidang perkebunan dan pengusahaan hutan. Dari hasil investigasi Yayasan Lembaga Bantuan Hukum Indonesia (YLBHI), didapatkan bahwa PT. Barat Selatan Makmur Investindo (BSMI) mendapatkan ijin lokasi dari Badan Pertanahan Nasional (BPN) RI pada 1994 untuk tanah seluas 10.000 hektar untuk kebun inti dan 5.000 hektar untuk kebun plasma. PT. BSMI lalu memperluas areal kebun sawitnya 2.455 hektar di luar izin yang dikeluarkan BPN. Izin Pengusahaan Hutan juga dikeluarkan Menteri Kehutanan untuk PT. Silva Inhutani pada tahun 1991 di atas tanah seluas 32.600 hektar. Sementara PT. Sumber Wangi Alam, diduga mengambil alih tanah masyarakat Desa Sungai Sodong seluas 1.533 hektar untuk perkebunan sawit.

Pemberian izin bagi berbagai perusahaan tersebut tidak dengan mempertimbangkan keberadaan suatu penduduk desa yang terlebih dahulu ada di atas tanahtanah tersebut. Masyarakat tak dimintai persetujuan atas keluarnya perijinan tersebut. Pemicu konflik agraria di areal HTI Register 45 Sungai Buaya adalah karena pemerintah telah memperluas luas kawasan hutan dimana sebagian tanah itu merupakan tanah adat. Tuntutan penduduk Desa Gunung Batu untuk pengembalian tanah yang diambil alih perusahaan seluas 7.000 hektar, hanya dikabulkan pemerintah seluas 2.300 hektar untuk kemudian dienclave dari kawasan HTI. Ironisnya, dari pihak perusahaan dan aparat menuduh penduduk desa itu dituduh sebagai perambah hutan (Siaran Pers YLBHI, WALHI, Sawit Watch, KPSHK, HuMa, SPI, 16 Desember 2011).

Perampasan tanah yang dilakukan oleh pemerintah dan perusahaan perkebunan, membuat penduduk yang menyebut dirinya sebagai masyarakat adat, terusir dari tempat tinggalnya. Padahal, bagi mereka tanah adalah syarat keberlanjutan kehidupannya. Karena itu, mereka kembali menuntut pengembalian tanahtanah adat khususnya setelah masa reformasi 1998. Sayangnya, penuntutan kembali hak-hak atas tanah oleh masyarakat adat ini direspon secara represif oleh aparat negara dan perusahaan. Hal tersebut terungkap pada awal Desember tahun 2011, dimana publik Indonesia disentakkan dengan pengaduan perwakilan masyarakat beberapa desa di Mesuji Lampung kepada wakil rakyat di Dewan Perwakilan Rakyat RI. Mereka mengadukan peristiwa pembunuhan sekitar 30 orang masyarakat desa di sekitar lokasi perkebunan sawit di Kabupaten Mesuji, Lampung dan Sumatera Selatan. Peristiwa itu terjadi antara 2009-2011. Hingga saat ini konflik ini masih belum menemukan tititk terangnya (S. Rahma Mary H. dan Noer Fauzi R., 2011:1). Dari beberapa kasus di atas dapat diketahui bahwa terdapat 3 materi konflik yang perlu lebih dalam dikaji (Martua Sirait, dkk, hal. 22):

Pertama, Konflik kewenangan atas ruang. Dalam kurun waktu beberapa dekade ini terjadi perampasan kawasan atau perampasan teritori (territory violence) terhadap masyarakat adat yang dilakukan atas nama undang-undang, peraturan dan kebijakan, sehingga menciptakan dua kelompok, yaitu kelompok yang diuntungkan (the winners), dan yang dipinggirkan (the loosers). Bentuk penguasaan kembali territory oleh kelompok masyarakat adalah bentuk pelampiasan dari proses peminggiran yang terjadi. Akan tetapi dalam menata ulang wilayah tersebut haruslah jeli melihat apakah masyarakat ini adalah: 1. masyarakat adat yang memiliki ikatan atas wilayah adat sebagai tanah leluhur (ancestral domain of the first nation) dan juga secara fisik menempati dan menggunakannya; 2. masyarakat adat yang mana memiliki ikatan atas wilayah adat sebagai tanah leluluhurnya tetapi tidak menempati dan secara fisik tidak mengunakannya karena suatu kesukarelaan atau paksaan dimana harus diperlakukan secara berbeda pula; 3. masyarakat heterogen (campuran antara masyarakat adat dan pendatang), dimana wilayah kampung atau desanya dinyatakan oleh pemerintah secara sepihak sebagai kawasan hutan. Sehingga akses masyarakat terhadap sebagian atau seluruh wilayah kampungnya menjadi hilang dan/atau terhambat; 4. merupakan klaim dari masyarakat pendatang yang mempunyai kekuatan hukum atas kepemilikan tanah di wilayah tersebut, misalnya transmigran program pemerintah yang hak milik atas tanahnya pada kemudian hari diketahui bahwa tanah tersebut merupakan kawasan hutan yang tidak dapat dimiliki atau hak kepemilikannya dicabut; 5. masyarakat pendatang lainnya yang telah datang ke tempat tersebut dan berminat untuk ikut mengelola 
hutan; 6. masyarakat pendatang yang berencana dan berkeinginan mengelola hutan.

Kedua, Konflik atas keberadaan masyarakat adat, kelembagaan dan kewenangannya. Masyarakat adat sebagai suatu kesatuan masyarakat yang otonom, memiliki sebuah sistem pengaturan yang tumbuh dan berkembang dari masyarakat itu sendiri dengan kesepakatan masyarakat sekitarnya. Masyarakat adat tersebut memiliki tata hukum serta nilai sendiri yang berlaku di dalam batas wilayah adatnya sehingga dikatakan otonom. Intervensi yang terlalu berlebihan dari pihak luar (pemerintah) dapat merusak bentuk pengaturan tentang kewenangan dari masyarakat adat yang telah berjalan dan berakibat runtuhnya sistem dan pola pengelolaan yang dimiliki. Ini sering terjadi dengan adanya penetapan-penetapan dari pemerintah pada saat melakukan intervensi terlalu jauh terhadap suatu sistem yang sudah cukup mandiri. Sehingga penilaian keberadaan masyarakat adat oleh pihak luar yang tidak mengerti tentang bentuk pengaturan yang ada dikawatirkan mengganggu tatanan yang telah terbentuk sekian lama. Contohnya nyata adalah bentuk pemaksaan Lembaga Ketahanan Masyarakat Desa sebagai satu-satunya organisasi di dalam Desa di seluruh Indonesia yang tidak memberikan tempat yang nyata kepada bentuk kelembagaan adat.

Ketiga, Konflik atas pola pengelolaan sumber daya. Konflik atas pola pengelolaan yang ada pada masyarakat adat sering terjadi dengan memisahkan suatu pola pengelolaan dari sistemnya. Contoh pola pengelolaan yang jelas adalah perladangan gilir balik yang hanya melihat ladang yang sedang dikerjakan saja tanpa melihat lahan beranya, serta pola-pola lain dalam sistem pengelolaan sumber daya alam. Perladangan gilir balik harus dapat dilihat sebagai suatu sistem yang menyatu dengan pola sawah yang ada di beberapa bagian kampung, hutan tutupan, kebun wanatani, sungai hutan tempat berburu bahkan tempat-tempat keramat. Miden (1995), membagi pola pengelolaan sumber daya alam di dalam wilayah adat Binua Dayak Kanayatn (Benua Talaga, dimana beliau menjabat sebagai salah seorang Timanggong) merupakan kombinasi atas: Pola penggunaan lahan berdasarkan ketinggiannya; Pola penggunaan lahan berdasarkan vegetasinya; Pola penggunaan lahan berdasarkan penguasaannya (perorangan, keluarga, klan, kampung atau Binua).

KPSHK berusaha meyakinkan para rimbawan bahwa wilayah adat merupakan suatu sistem dimana terdapat beberapa pola, diantaranya pola hutan adat, pola pemukiman, pola pertanian, dan sebagainya yang tidak dapat dipisah-pisahkan dan bersifat dinamis.
Beberapa contoh kasus konflik yang terjadi di atas dapat pula menunjukkan intensitas konflik yang berbeda pula antara konflik yang satu dengan yang lainnya antara lain (Martua Sirait, dkk, hal. 23): Pertama, Konflik tersembunyi (laten). Dicirikan dengan adanya tekanan-tekanan yang tidak nampak sepenuhnya berkembang dan belum terangkat ke puncak kutub-kutub konflik. Seringkali satu atau dua pihak belum menyadari adanya konflik. Konflik tersembunyi dapat terjadi dengan adanya penunjukan status kawasan hutan negara secara sepihak tanpa melibatkan masyarakat dalam proses penetapannya, pemberian hak pengusahaan hutan atau kebun pada kawasan yang belum ditetapkan sebagai kawasan hutan negara dan sebagainya. Model seperti ini banyak terjadi dimana-mana di Indonesia, dimana masyarakat tidak menyadari bahwa status tanahnya secara sepihak ditunjuk atau bahkan telah ditetapkan sebagai kawasan hutan negara. Kedua, Konflik mencuat (emerging). Perselisihan dimana pihak-pihak yang berselisih dapat teridentifikasi. Mereka mengakui adanya perselisihan, kebanyakan permasalahannya jelas, tapi proses dan penyelesaiannya belum dikembangkan. Konflik ini biasanya dirasakan di lapangan pada saat perusahaan memulai aktifltasnya, dan pada saat itu masyarakat adat serta pihak yang mendapatkan hak atau ijin menyadari akan adanya tumpang tindih kewenangan. Ketiga, Konflik terbuka. Konflik dimana pihak-pihak yang berselisih secara aktif terlibat dalam perselisihan yang terjadi dan mungkin sudah mulai bernegosiasi, dan mungkin juga akan menemui jalan buntu dan memungkinkan digunakannya cara-cara kekerasan oleh kedua belah pihak.

Eksistensi akan masyarakat adat adalah suatu kenyataan sejarah yang mana tidak dapat dihindari atau disangkal oleh pemerintah. Masyarakat adat merupakan suatu segmen riil di dalam masyarakat Indonesia. Secara formal pengakuan, penerimaan, atau pembenaran adanya masyarakat adat di dalam struktur ketatanegaraan baru diatur di dalam Pasal 18 Undang-Undang Dasar 1945 (selanjutnya disebut UUD 1945). Sebagaimana ditegaskan pada penjelasan pasal tersebut; secara sebagian-sebagian pengakuan, penerimaan, dan/atau pembenaran terhadap adanya masyarakat adat terdapat di dalam beberapa peraturan perundang-undangan, padahal dalam lingkup pergaulan internasional pemerintah Republik Indonesia masih bersikap setengah hati mengakui, menerima, membenarkan adanya masyarakat adat dengan segala hak dan kewajibannya, di tengah-tengah pengakuan, penerimaan dan pembenaran yang telah dilakukan oleh negara lain, antara lain Filipina dan Malaysia. 
Adanya keadaan "belum mengakui, menerima atau membenarkan" ini merupakan potensi konflik bahkan ancaman disintegrasi. Terdapat pemikiran yang keliru di kalangan pemegang kekuasaan di Indonesia saat ini bahwa apa yang disebut masyarakat adat adalah sesuatu yang semu atau sesuatu yang sudah tidak ada lagi, sejak Indonesia menjadi suatu organisasi negara modern dengan nama Republik berbentuk Kesatuan. Oleh karena itu ada kecenderungan kuat untuk menghapuskannya.

Dari keadaan dan rumusan tentang masyarakat adat dan masyarakat hukum adat yang dikemukakan para pakar di atas serta karakteristik dalam mengelola sumberdaya alam, tampaknya ada bagian-bagian telah diatur dan juga ada bagian yang belum diatur dalam peraturan perundang-undangan, dan bahkan ada peraturan yang saling tumpang tindih. Bagian yang belum diatur dapat dibuat aturan baru untuk melengkapinya, sedangkan pada bagian yang sudah diatur dapat diikuti dengan cara mengkritisinya, sedangkan bagian yang tumpang tindih pengaturannya perlu ditelaah mana yang lebih tepat.

Terdapat beberapa prinsip-prinsip yang merupakan landasan bagi kebijakan tentang hak-hak masyarakat hukum adat antara Tanah Negara (Public Land), Tanah Milik (Private Land), dan Hutan Negara (Public Forest), Hutan Milik (Private Forest) (Martua Sirait, $\mathrm{dkk}$, hal 24).

Pembicaraan tentang tanah serta hutan adalah berbicara tentang dua hal yang berbeda. Pengaturan hak atas hutan tidak akan berbicara tentang hak-hak kepemilikan (land-rights), tetapi berbicara tentang hak-hak untuk menggunakan hutan termasuk dalam lingkup hak penggunaannya (use-rights).

Dalam menyelesaikan masalah-masalah sumber daya hutan, perlu adanya kejelasan penetapan hak untuk mengunakan hutan, dan dilakukan atas dasar status penguasaan hutan, maupun berdasarkan atas fungsi lindung, konservasi, produksi maupun fungsi khusus di bidang sosial budaya maupun pendidikan dan penelitian. Dalam Undang-Undang Kehutanan No. 41 Tahun 1999, Departemen Kehutanan diberikan mandat untuk menetapkan mana yang merupakan kawasan hutan dan mana yang bukan, serta juga menetapkan fungsi hutannya. Seharusnya Departemen Kehutanan hanya menetapkan fungsi bukan statusnya, untuk mencegah conflict of interest.

Sehingga sebaiknya ditetapkan adanya kawasan hutan negara (public forest), yang dilakukan melalui proses pengukuhan hutan secara partisipatif sehingga penetapan status hutan menjadi legal dan legitimate. Dengan ini, Surat Keputusan Menteri Kehutanan No.
634/Kpts-II/1996 tentang Pengukuhan Hutan serta SK 635/Kpts-II/1996 tentang Panitia Tata Batas perlu direvisi segera.

Surat Keputusan ini harus dipersiapkan untuk menjadi proses yang partisipatif, transparan serta bertanggungjawab. Penandatanganan Berita Acara Tata Batas (BATB) harus dilakukan oleh pemilik lahan (masyarakat adat) yang mengakui ada atau tidaknya hak-hak masyarakat di dalam kawasan hutan yang ditata batas. Demikian juga untuk wilayah-wilayah di dalam kawasan hutan yang telah ditata batas dapat diakomodir dengan penyelesaian Encalve, dimana dilaksanakan tidak dengan sistem scoring akan tetapi dilaksanakan secara partisipatif bersama-sama dengan Panitia Tata Batas. Proses ini perlu didesentralisasikan ke daerah lebih dari sekedarnya seperti yang diatur dalam PP No. 62 Tahun 1998. Pola pembuktian hak atas tanah dilakukan dengan rasa tanggung jawab, dimana kedua belah pihak (masyarakat adat serta Deptanhut) mengeluarkan argumentasi serta buktibukti penguasaan lahannya sesuai dengan PP No. 24 tahun 1997 tentang Pendaftaran Tanah, dimana pembuktiannya dapat berupa pembuktian tertulis, pengakuan lisan dan pembuktian fisik.

Selain BPN (yang mengenal Tanah Negara dan Tanah Milik) dan Dephut (mengenal Hutan Negara dan Hutan Milik), Departemen Dalam Negeri mengenal juga tanah, antara lain Tanah Desa, Perairan atau Pantai, Pemancingan serta sumber daya alam Desa.

Dengan adanya departemen yang mana berwenang atas penetapan status atas tanah dengan kriteria yang berbeda, menimbulkan konflik status tanah, mana yang merupakan Tanah Negara (public land) dan mana yang bukan (private land) menurut kriteria yang berbeda pula. Dilihat dari keberadaan UUPA dan UUPK seharusnya UUPA No. 5 Tahun 1960 yang lahir lebih dulu harus diacu oleh UUPK No. 5 Tahun 1967 maupun penggantinya yaitu UUK No. 41 Tahun 1999 mengatur bentuk-bentuk penguasaan atas sumber-sumber agraris termasuk hutan didalamnya. Sehingga kriteria atas tanah dan kawasan hutan negara sama dan pengaturannya tidak tumpang tindih.

Dengan terbitnya Permen BPN No. 5 Tahun 1999 dijelaskan bahwa Tanah Ulayat dapat didaftarkan menjadi kepemilikan adat, dapat menjadi hak milik perorangan bila ingin dimiliki secara perorangan dan dapat juga dipinjamkan kepada pemerintah untuk diberikan HGU kepada pihak lain pada jangka waktu yang disepakati. Bentuk pengakuan tanah ulayat tidak sama dengan tanah perorangan bersertifikat, tanah ulayat didaftarkan pada buku register tanah, dilampiri peta dan tidak dapat dipindahtangankan. 
Perbedaan pendapat antara BPN dengan Dephut mengenai sistem penguasaan tanah (land tenure) salah satunya dapat diselesaikan melalui amandemen UUD dan dibuatnya suatu payung undang-undang yang mengatur atas penguasaan atas sumber daya alam. Tim LandReform yang dibentuk oleh Pemerintah pada tanggal 27 Mei 1999 ditujukan untuk menyelaraskan undang-undang serta beberapa peraturan lainnya yang menyangkut pertanahan (Keppres No. 48 tahun 1999) dan revisi UU Kehutanan saat lalu dirasa tidak efektif untuk mengoreksi miskonsepsi terdahulu. Bentuk penyelarasan undang-undang dengan melibatkan publik secara luas perlu dilanjutkan dengan lebih transparan dan legible.

Departemen Kehutanan dalam mengakomodir hak masyarakat hukum adat atas penguasaan hutan perlu memisahkan antara sumber daya hutan dan tanahnya. Hak penguasaan atas tanah (land tenure) adatnya diatur oleh BPN, sedangkan bagi pengelolaan sumber daya hutan (forest resource management) adatnya diatur oleh Departemen Kehutanan atau instansi lainnya yang mengatur mengenai sumber daya alam, misal Depdagri dalam mengatur sumber daya alam milik Desa.

Prinsip-prinsip yang merupakan landasan bagi kebijakan tentang hak-hak masyarakat hukum adat antara Pemberian Hak (Granting) dan Pengakuan Hak (Recognition). Masyarakat hukum adat yang bersifat otonom (suatu kesatuan masyarakat adat yang lahir atau dibentuk oleh masyarakat itu sendiri) memiliki hak yang bersifat original atau sesuatu hak asli yang diciptakan sendiri sebelum adanya pengaturan hak lainnya, atau dikenal dalam istilah hukum a prima facie yang mengatur terlebih dahulu. Sedangkan yang diatur mencakup atas tanah dan sumber daya hutan lainnya. Sedangkan hak-hak yang biasa dikenal dalam bidang kehutanan bersifat Derivat atau pemberian hak atas penguasaan oleh negara contohnya adalah $\mathrm{HPH}$, HPHTI, HPP, HPHKM dan lain-lain. Sehingga hak yang diterbitkan oleh pemerintah kepada masyarakat adat adalah Hak yang bersifat Pengakuan.

Hak ini dikenal di BPN pada saat penerbitan Hak Milik atas tanah, jelas dikatakan hak tersebut didapat dari negara atau dari hak adat. Bila hak tersebut berasal dari tanah negara maka bentuk haknya adalah pemberian (granting) yang dapat ditarik kembali oleh negara sedangkan bila hak tersebut berasal dari hak adat maka bentuknya adalah pengakuan (recognition) yang tak dapat ditarik kembali oleh negara. Pengakuan dalam arti ini menegaskan suatu sifat pembenaran atau penerimaan oleh pemerintah terhadap hak-hak masyarakat adat yang a prima facie telah melekat pada masyarakat adat. Sehingga untuk mencegah konflik pertanahan dan sumber daya hutan, penerbitan hak kepada pihak lain oleh pemerintah tidak dapat dilakukan pada wilayah-wilayah masyarakat hukum adat yang mempunyai a prima facie dan diakui oleh pemerintah. Sehingga pada kawasan yang belum dapat dibuktikan pemerintah bahwa tidak ada hak-hak masyarakat adat atas tanah dan sumber daya alamnya, tidak dapat diterbitkan hak untuk pihak lain.

Prinsip yang merupakan landasan bagi kebijakan tentang Pengakuan Masyarakat Adat sebagai badan hukum. Dengan terbitnya SK Mendagri No. 3 tahun 1997 tentang Pemberdayaan dan Pelestarian Serta Pengembangan Adat Istiadat, Kebiasaan-kebiasaan Masyarakat, dan Lembaga Adat di Daerah, dapat disimpulkan bahwa sifat lembaga adat yang dapat mewakili masyarakatnya keluar dan juga ke dalam untuk melakukan beragam kegiatan serta wewenang kelembagaan adat mengatur kekayaannya termasuk sumber daya alamnya yang merupakan bukti bahwa masyarakat adat diakui sebagai suatu badan hukum yang dapat melakukan perbuatan-perbuatan hukum, termasuk menerima dan diakui haknya. Sehingga dalam hal ini masyarakat hukum adat tidak perlu membentuk Koperasi, badan hukum atau bahkan badan usaha lainnya untuk melakukan aktifitasnya dalam pengelolaan hutan. Akan tetapi dengan adanya kehadiran SK Mendagri yang relatif baru ini perlu dikritisi lebih lanjut oleh karena masyarakat adat dan kelembagannya baru akan diakui atau dihargai kehadirannya dan perannya, sementara mekanisme yang harus ditempuh belum jelas.

Peran masyarakat adat dan pengurus adat dalam Peraturan Menteri Agraria No. 5 tahun 1999 lebih diperjelas dimana kepunyaan tetap pada masyarakat adat sedangkan pengurus adat, sebagai petugas yang mendapat wewenang dari masyarakat adat untuk mengurusnya.

Prinsip yang merupakan landasan bagi kebijakan tentang Hak-Hak Masyarakat Adat atas Tanah dan Sumber Daya Alamnya dan Hak-Hak Masyarakat Adat Lainnya. Hak-hak masyarakat adat sampai saat ini lebih banyak terpusat pada hak-hak atas tanah (land rights) dan sumber daya alamnya (resorce rights) yang terlihat akan tetapi cenderung mengabaikan hakhak milik masyarakat adat lainnya yang tidak terlihat misalnya hak-hak kepemilikan intelektual (intelectual property right) atas temuan obat-obatan tradisional serta hak-hak masyarakat adat atas keamanan hayati yang berasal dari proses budidaya (biosafety) yang bersumber dari pengetahuan adat dan juga wilayah adatnya. Perlindungan dan pemajuan masyarakat 
adat atas hak-hak intelektual masyarakat adat dan keamanan hayati adat dari penjarah-penjarah hak paten hayati (bio piracy) dan penjarah-penjarah hak intelektual (intelectual piracy), serta perlindungan atas bio prospeksi lainnya perlu ditekankan.

Dalam ratifikasi United Nations Convention on Biological Diversity dalam bentuk undang-undang telah dilakukan akan tetapi perlu dijabarkan dalam Peraturan Pemerintah dan Surat Keputusan Menteri yang berwenang. Sehingga Departemen Kehutanan dan Perkebunan dalam kebijakannya yang nantinya akan mengakomodir hak-hak masyarakat hukum adat, harus dapat menterjemahkan hak-hak masyarakat hukum adat yang tidak hanya pada hak pengelolaan sumber daya hutan berupa kayu, tetapi lebih luas yaitu sampai kepada perlindungan dan pemajuan hak-hak intelektual dan keamanan hayati sebagaimana penjabaran dari Undang-Undang No. 5 tahun 1994 tentang Pengesahan United Nations Convention on Biological Diversity (Konvensi Perserikatan BangsaBangsa mengenai Keanekaragaman Hayati).

\section{Keberadaan Masyarakat Hukum Adat}

Ada berbagai produk hukum nasional yang mana mengakui akan adanya suatu keberadaan masyarakat hukum adat yang ada di Indonesia. Dalam UUD 1945, pengakuan dan penghormatan terhadap masyarakat hukum adat, termaktub di dalam pasal 18B ayat 2, yaitu Negara mengakui dan menghormati kesatuankesatuan masyarakat hukum adat beserta hak-hak tradisionalnya sepanjang masih hidup dan sesuai dengan perkembangan masyarakat Indonesia dan prinsip Negara Kesatuan Republik Indonesia, yang diatur dalam undang-undang.

Pasal ini, memberikan posisi konstitusif pada masyarakat hukum adat dalam hubungannya dengan negara, serta menjadi landasan konstitusional bagi pihak penyelenggara negara, bagaimana seharusnya komunitas diperlakukan. Dengan demikian pasal tersebut adalah satu deklarasi tentang kewajiban konstitusional bagi negara untuk mengakui dan juga menghormati masyarakat adat, dan juga sebagai hak konstitusional masyarakat adat untuk memperoleh pengakuan serta penghormatan terhadap hak-hak tradisionalnya.

Apa yang termaktub di dalam Pasal 18B ayat 2 tersebut, sekaligus merupakan mandat konstitusi yang harus ditaati oleh pihak penyelenggara negara, untuk mengatur pengakuan dan penghormatan atas keberadaan masyarakat adat dalam suatu bentuk undang-undang. Pasal lain yang berkaitan dengan masyarakat adat diatur dalam Pasal 28I ayat 3 UUD
1945, yang menyebutkan identitas budaya dan hak masyarakat tradisional harus dihormati selaras dengan perkembangan zaman dan peradaban.

Sebelum Amandemen terhadap UUD 1945, TAP MPR No. XVII/1998 tentang Hak Asasi Manusia (yang selanjutnya disebut HAM) terlebih dahulu memuat suatu ketentuan tentang pengakuan atas hak masyarakat adat. Dalam Pasal 41 Piagam HAM yang menjadi bagian tak terpisahkan dari TAP MPR itu, ditegaskan identitas budaya masyarakat tradisional, termasuk hak atas tanah ulayat dilindungi, selaras dengan perkembangan zaman.

Dengan diaturnya pasal ini, maka hak-hak dari masyarakat adat yang ada, ditetapkan sebagai salah satu hak asasi manusia yang wajib dihormati, dan salah satu hak itu menurut pasal ini adalah hak atas tanah ulayat.

Bahkan di dalam TAP MPR No. IX/2001 tentang Pembaharuan Agraria dan Pengelolaan Sumber Daya Alam (yang selanjutnya disebut PSDA), hak-hak masyarakat adat tersebut tidak hanya sebatas hak atas tanah ulayat, tetapi juga menyangkut sumberdaya agraria atau sumberdaya alam, termasuk keragaman budaya dalam pengelolaan dan pemanfaatannya. Hal itu termaktub dalam pasal 4, bahwa Pembaruan agraria dan pengelolaan sumber daya alam harus dilakukan sesuai dengan prinsip-prinsip: mengakui, menghormati, dan melindungi hak masyarakat hukum adat dan keragaman budaya bangsa atas sumber daya agraria atau sumber daya alam.

Awal mulanya TAP MPR No. IX/2001 itu lahir dilatarbelakangi dengan adanya situasi empirik PSDA yang bersifat sentralistik, eksploitatif, memiskinkan rakyat banyak (termasuk masyarakat hukum adat), ketimpangan struktur penguasaan dan kepemilikan, serta kerusakan lingkungan hidup yang masif. Karena itu, TAP MPR ini, mengamanatkan agar dilakukannya pembaharuan agraria oleh pemerintah dalam hal PSDA berdasarkan prinsip-prinsip penghargaan atas HAM, demokratisasi, transparansi, dan partisipasi rakyat, keadilan penguasaan dan kepemilikan, serta pengakuan, penghormatan, dan perlindungan terhadap masyarakat adat.

Pada tingkatan undang-undang, Undang-Undang Pokok Agraria (yang selanjutnya disebut UUPA) No. 5 Tahun 1960 adalah produk hukum yang pertama kali menegaskan pengakuannya atas hukum adat. Ketentuan ini dapat dilihat di Pasal 5 UUPA yang menyebutkan bahwa hukum agraria yang berlaku atas bumi, air dan ruang angkasa ialah hukum adat, sepanjang tidak bertentangan dengan kepentingan nasional dan negara yang didasarkan atas persatuan 
bangsa. Serta merupakan rumusan atas kesadaran dan kenyataan bahwa sebagian besar rakyat tunduk pada hukum adat, sehingga kesadaran hukum yang dimiliki bangsa Indonesia adalah kesadaran hukum berdasarkan adat. Hanya saja memang semangat UUPA ini, dikemudian waktu banyak ditinggalkan, karena adanya pergeseran politik ekonomi dan hukum agraria. Kendati demikian, UU ini hingga sekarang masih menjadi hukum yang positif yang mengatur mengenai agraria. Karenanya masih menjadi alat legal dalam memperkuat hak-hak komunitas adat. Namun seiring dengan arus reformasi, kesadaran terhadap pengakuan, penghormatan dan perlindungan hakhak masyarakat hukum adat menjadi salah satu isu politik yang mengemuka. Sejumlah undang-undang telah diproduk menyertai UUPA, seperti yang akan diuraikan di bawah ini.

UU No. 39 tahun 1999 tentang HAM ini dapat dikatakan sebagai operasionalisasi dari TAP MPR XVII/1998, yang mana menegaskan bahwa hak-hak masyarakat hukum adat sebagai bagian dari Hak Asasi Manusia yang tertuang dalam Pasal 6 UU No. 39 Tahun 1999 yang memuat tentang penegakan HAM, perbedaan dan kebutuhan dalam masyarakat hukum adat harus diperhatikan dan dilindungi oleh hukum, masyarakat, dan pemerintah serta identitas budaya masyarakat hukum adat, termasuk hak atas tanah ulayat dilindungi, selaras dengan perkembangan jaman.

Kondisi masyarakat hukum adat itu dapat dibagi ke dalam tiga kelompok, yaitu (Jimly Asshiddiqie, 2007: 8): 1. kesatuan masyarakat hukum adat yang sudah mati sama sekali; 2. kesatuan masyarakat hukum adat yang sudah tidak hidup dalam praktek tetapi belum mati sama sekali sehingga masih dapat diberi pupuk agar dapat hidup subur; 3. kesatuan masyarakat hukum adat yang memang masih hidup.

Masyarakat hukum adat yang dapat dikategorikan tidak hidup lagi, dengan kata lain sudah mati sama sekali adalah: 1. Masyarakatnya sudah tidak asli lagi, tradisinya pun sudah tiada dan catatannya pun tidak ada, kecuali hanya ada dalam legenda-legenda yang tidak tertulis; 2 . Masyarakatnya tidak asli lagi, tradisinya pun sudah menghilang dari praktek, tetapi catatannya masih tersedia dan sewaktu-waktu dapat dihidupkan lagi; 3. Masyarakatnya memang masih asli, tetapi tradisinya sudah tiada, dan tidak ada pula catatan sama sekali (Jimly Asshiddiqie, 2007:8).

Ketiga kategori masyarakat hukum adat tersebut di atas, tidak dapat lagi dikatakan hidup. Sekiranya pun catatan tentang tradisi asli itu masih tersimpan baik seperti pada kategori kedua, tetapi ini tidak dapat dikatakan masih hidup. Kalaupun dihidupkan kembali karena catatannya masih lengkap, misalnya untuk kepentingan industri pariwisata, tentu saja namanya bukan lagi masyarakat hukum adat yang bersangkutan. Demikian pula pada kategori ketiga, meskipun masyarakatnya masih asli, tetapi tradisinya tidak dipraktekkan lagi dan catatannya pun tidak tersedia. Sekiranya ingin dihidupkan kembali, hal tersebut tidak menjamin bahwa tradisi yang dimaksud memang sesuai dengan tradisi hukum adat yang mana memang pernah dipraktekkan sebelumnya. Karena itu, pengertian kesatuan masyarakat hukum adat yang hidup seperti dimaksud salah satunya dalam Pasal 18B ayat 2 UUD 1945, tidak mencakup ketiga kategori kesatuan masyarakat hukum adat sebagaimana telah diuraikan di atas.

Sementara itu, kelompok kategori kedua adalah masyarakat hukum adat yang masih dapat dihidupkan, yaitu masyarakat hukum adat yang masih asli, tetapi tradisinya tidak dipraktekkan lagi, namun tersedia rekaman atau catatan tertulis yang cukup memadai untuk dipupuk kembali. Aktivitas hukum adat di masyarakat hukum adat kategori ini mungkin tidak terlihat lagi dalam kegiatan praktek sehari-hari.

Akan tetapi, gagasan-gagasan dasarnya masih tersimpan dalam impian dan dalam cara pandang masyarakatnya yang juga masih asli dalam arti bukan terdiri atas para pendatang baru, dan rekaman atau catatan mengenai tradisi dimaksud juga masih tersedia dengan baik. Menghilangnya tradisi hukum adat yang bersangkutan dari kegiatan praktek sehari-hari, sangat mungkin disebabkan oleh banyak faktor, termasuk karena adanya intervensi kebijakan pemerintahan secara terpusat dan seragam secara nasional yang diterapkan selama ini, yang mana mengakibatkan hancurnya berbagai sendi hukum adat di berbagai kalangan masyarakat hukum adat asli di tanah air.

Kesatuan masyarakat hukum adat seperti ini, yaitu yang masyarakatnya masih asli, tetapi tradisinya tidak dipraktekkan, namun tersedia rekaman atau catatan tertulis, masih dapat dihidupkan kembali sebagaimana mestinya, asalkan memenuhi beberapa persyaratan, yaitu: 1. sesuai dengan perkembangan masyarakat menuju ke tingkat peradaban yang semakin maju; 2. sesuai dengan prinsip Negara Kesatuan Republik Indonesia; dan 3. diatur dilakukan menurut aturan yang ditentukan dalam undang-undang yang berkaitan (Jimly Asshiddiqie, 2007:10).

Artinya, meskipun kesatuan masyarakat hukum adat yang termasuk dalam kategori ini masih dapat dihidupkan lagi, tetapi untuk itu harus diperhatikan ketiga syarat tersebut. Jika nilai-nilai hukum adat yang terkandung di dalamnya tidak sesuai lagi dengan 
perkembangan rasa kemanusiaan di zaman sekarang, misalnya, tradisi balas dendam berdarah, tentu tidak boleh dihidupkan kembali karena tidak sesuai dengan perkembangan masyarakat.

Demikian pula apabila tradisi masyarakat hukum adat yang bersangkutan itu bertentangan ataupun dapat mengakibatkan terganggunya upaya dalam rangka mempertahankan dan memperkuat prinsip Negara Kesatuan Republik Indonesia, tentu juga tidak boleh dihidupkan lagi. Misalnya jika ada satu kesatuan masyarakat hukum adat di daerah perbatasan yang lebih berorientasi kepada kesatuan masyarakat hukum adat yang berpusat di negara lain di perbatasan, tentu dapat membahayakan prinsip Negara Kesatuan Republik Indonesia.

Kelompok yang ketiga adalah kategori masyarakat hukum adat yang memang dapat dikategorikan masih hidup dalam kenyataan, yaitu: 1 . Masyarakat masih asli, tradisinya juga masih dipraktekkan, dan tersedia catatan mengenai tradisi tersebut; 2 . Masyarakatnya masih asli tradisinya masih ada, tetapi catatan tidak tersedia; 3. Masyarakatnya sudah tidak asli lagi, tetapi tradisinya masih dipraktekkan dan catatannya pun tersedia cukup memadai; 4 . Masyarakatnya tidak asli lagi, dan juga tidak tersedia catatan mengenai hal itu, tetapi tradisinya masih hidup dalam praktek (Jimly Asshiddiqie, 2007:10).

Meskipun dalam praktek sangat dimungkinkan tidak akan pernah menjadi kenyataan, tetapi secara teoritis mungkin saja terjadi adanya kategori ketiga dan keempat dari penjelasan di atas. Persoalannya adalah apakah keaslian warga masyarakat di dalam kesatuan masyarakat hukum adat yang bersangkutan merupakan faktor yang menentukan atau tidak untuk menentukan hidup matinya suatu masyarakat hukum adat? Jika ukuran utamanya adalah tradisi hukum adatnya, maka meskipun orangnya sudah berganti dengan para pendatang baru, selama tradisinya masih hidup dalam praktek, maka dapat saja dikatakan bahwa masyarakat hukum adat yang bersangkutan masih hidup.

Tetapi dalam kenyataan praktek, apakah mungkin terjadi dimana warga masyarakatnya yang sudah berganti dengan para pendatang, tetapi tradisi asli masyarakat yang bersangkutan tetap bertahan hidup dalam praktek sehari-hari. Oleh karena itu, untuk kemudahan, kemungkinan ini dimasukkan ke dalam kategori kesatuan masyarakat hukum adat yang masih hidup.

Keberadaan masyarakat hukum adat ini dapat dinilai sangat strategis, oleh karena itu kepentingan peningkatan keberdayaannya dipandang perlu untuk diadakan inventarisasi secara nasional, meskipun Undang-Undang tentang Pemerintahan Daerah telah menentukan bahwa penentuan masyarakat hukum adat yang masih hidup dilakukan oleh pemerintah daerah. Tidak terlalu tepat bilamana memberikan kewenangan itu kepada pemerintah daerah tanpa pedoman substantif yang dapat dijadikan pegangan menyeluruh. Jika mati hidup suatu masyarakat hukum adat sepenuhnya diserahkan kepada kewenangan regulasi di tingkat kabupaten dan kota tanpa ramburambu yang jelas, tentulah cukup besar risikonya. Hal itu karena keberadaan kesatuan masyarakat hukum adat pada banyak kasus melintasi batas-batas wilayah administratif kabupaten dan kota, bahkan propinsi. Hal itu dapat memicu timbulnya konflik, baik antar daerah maupun antara pemerintah daerah dengan masyarakat hukum adat tertentu. Disisi lain, tanpa adanya pedoman substantif yang menyeluruh dapat terjadi diskriminasi terhadap masyarakat adat hanya karena perbedaan penafsiran yang dilakukan oleh pemerintahan daerah.

\section{PENUTUP \\ Kesimpulan}

Dengan demikian, Pemerintah Pusat, Pemerintah Daerah maupun legislatif serta kesatuan masyarakat adat dalam hal ini instansi yang mendapat wewenang mengakui, membenarkan dan menerima hak-hak masyarakat adat, perlu memahami beberapa aspek, yakni:

Pertama, Kewenangan atas wilayah masyarakat hukum adat. Masyarakat hukum adat mengenal betul wilayahnya dengan batas-batas jelas yang didapatkan melalui proses sejarah yang panjang. Oleh karena itu masyarakat adat perlu untuk mengkomunikasikan wilayah adatnya kepada masyarakat di sekitarnya, pemerintah, dan pihak lain dengan menggunakan bahasa (media) yang sama. Pelaksanaan ini dapat dengan cara menggunakan peta yang mana biasanya digunakan oleh Dephutbun maupun instansi lain, dimana dalam pembuatan peta tersebut dilaksanakan secara partisipatif dan dengan teknik yang sederhana, sehingga peta akan menjadi alat yang efektif untuk mendiskusikan tumpang tindih suatu wilayah dalam kewenangannya.

Kejelasan kewenangan atas wilayah masyarakat hukum adat dapat dilakukan berdasarkan kesepakatan dan pengakuan oleh masyarakat sekitar. Selanjutnya, diperlukan pengakuan yang tegas dari pemerintah agar wilayah masyarakat hukum adat itu tidak dialihkan haknya kepada pihak lain, sekaligus menjamin sumber daya hutannya dapat dimanfaatkan. 
Bentuk kejelasan kewenangan wilayah masyarakat hukum adat dapat dilakukan dalam bentuk pengakuan wilayah masyarakat hukum adat oleh BPN. Dalam hal wilayah masyarakat hukum adat yang terlebih dahulu diberikan sebelum surat keputusan ini terbit, dapat dinegosiasikan dengan para pihak yang bersangkutan (masyarakat hukum adat dalam wilayah tersebut, pemberi hak, dan penerima hak).

Pembuktian hak atas kewenangan suatu wilayah masyarakat hukum adat dapat mengikuti apa yang telah diatur dalam PP No. 24 Tahun 1997 tentang Pendaftaran Tanah. Dalam peraturan pemerintah tersebut pembuktian hak-hak lama (hak-hak milik atas tanah yang berasal dari hak adat) dapat dilakukan melalui: 1. Alat pembuktian secara tertulis (suratsurat tanah, waris, peta, laporan sejarah, dokumen serah terima, pengakuan tertulis dari masyarakat sekitarnya, dan lain-lain); 2. Alat pembuktian secara lisan (pengakuan lisan masyarakat sekitar tentang kewenangan atas wilayah adat tertentu, pemberian nama tempat dalam bahasa lokal, cerita, pantun, dan lain-lain); 3. Alat pembuktian secara fisik (kuburan nenek moyang, terasering bekas usaha tani, bekas perumahan, perkebunan buah, tumbuhan exotic hasil budidaya, peninggalan sejarah, gerabah, prasasti, dan lain-lain).

Kedua, adalah Kewenangan kelembagaan adat. Kewenangan suatu wilayah masyarakat hukum adat sangat diperlukan untuk mencegah adanya pengakuan ganda ataupun pengakuan atas suatu wilayah yang bukan kewenangannya. Dalam hal ini ada beberapa kemungkinan yang dapat dilakukan: 1. Pengakuan keberadaan masyarakat adat oleh masyarakat adat itu sendiri dan dengan pengakuan dari masyarakat sekitarnya tentang kewenangan kelembagaannya; 2 . Pengakuan keberadaaan masyarakat hukum adat oleh lembaga yudikatif berdasarkan putusan pengadilan; 3. Pengakuan keberadaan masyarakat adat oleh suatu Dewan Masyarakat Adat yang dipilih oleh Masyarakat Adat itu sendiri.

Ketiga, Kewenangan atas pola pengelolaan sumber daya hutan. Pola pengelolaan yang dilakukan oleh masyarakat hukum adat pada umumnya berdasarkan pengetahuan asli yang ada dan tumbuh di masyarakat dengan segala norma-norma yang mengatur akan batasan-batasan dan sanksi. Pola ini berkembang sangat dinamis sesuai dengan perkembangan zaman. Sifat dinamis ini pada umumnya tidak secara tegas mendefinisikan pengelolaan SDA berupa; hutan, kebun atau usaha pertanian, sehingga diperlukan pemahaman yang cukup oleh pemerintah daerah tentang pola-pola tersebut.
Terlepas dari kebaikan dan kelemahan akan 3 (tiga) pilihan di atas, nampaknya bentuk kombinasi kewenangan pengakuan tersebut perlu diatur, antara masyarakat di sekitar wilayah masyarakat hukum adat dan pemerintah bersama dengan masyarakat adat yang berkepentingan itu sendiri. Disamping mekanisme pengakuan tersebut, diperlukan juga suatu mekanisme naik banding dan penyelesaian sengketa antar masyarakat adat atas suatu kewenangan wilayah tertentu. Demikian pula bentuk penyelesaian sengketa di luar pengadilan untuk sengketa antar kelompok masyarakat adat yang mengklaim suatu wilayah yang sama perlu dipersiapkan.

Dalam menghidupkan kembali kesatuan hukum adat yang masyarakatnya masih asli, tetapi tradisinya sudah tidak dipraktekkan lagi yaitu bisa dilakukan dengan memenuhi beberapa persyaratan, antara lain: Pertama, sesuai dengan perkembangan masyarakat menuju ke tingkat peradaban yang semakin maju; Kedua, sesuai dengan prinsip-prinsip Negara Kesatuan Republik Indonesia; serta Ketiga, diatur dilakukan menurut aturan yang ditentukan dalam undang-undang yang berkaitan.

\section{Rekomendasi}

Hak-hak masyarakat hukum adat yang berupa hak ulayat, keberadaannya tetap diakui, sepanjang secara nyata masih ada, dan diberi kesempatan untuk memanfaatkan potensi hutan yang sejalan dengan pembangunan kehutanan.

Sejalan dengan UUPA No. 5 Tahun 1960, hak pengelolaan dapat diberikan kepada masyarakat hukum adat, masyarakat adat memerlukan kepastian hak yang bersifat khusus (ekslusif, tidak tumpang tindih dengan hak lain) dimana masyarakat dapat melestarikan dan memanfaatkan (termasuk juga membudidayakan), memasarkan hasil hutan, serta tidak dapat dipindahtangankan kepada pihak lain di luar masyarakat hukum adat tersebut.

\section{DAFTAR PUSTAKA}

Wignjodipuro, Soerojo, 1979, Pengantar dan AsasAsas Hukum Adat, Bandung: Alumni.

Sirait, Martua, dkk., Bagaimana Hak-Hak Masyarakat Hukum Adat dalam Mengelola Sumber Daya Alam Diatur, Southeast Asia Policy Research Working Paper, No. 24, hal. 5

Saleng, Abrar, 2004, Hukum Pertambangan, Yogyakarta: UII Press Andico Multiplay.

Sumardjani, Lisman, 2007, Konflik Sosial Kehutanan, Bogor.

Siradjudin, Azmi A. R., 2010, Pengakuan Masyarakat 
Adat dalam Instrumen Hukum Nasional, Sulawesi Tengah: Yayasan Merah Putih.

Asshiddiqie, Jimly, Hak Konstitusional Masyarakat Hukum Adat, Makalah disampaikan dalam Lokakarya Nasional, Jakarta 10 Desember 2007.

Tua, Perpatih Nan, 2006, Pola Hubungan Struktural antara Masyarakat Hukum Adat dengan Pemerintah Daerah, Perspektif dapat ditemukan dalam:
Frans Magnis Suseno, dkk., Hubungan Stuktural Masyarakat Hukum Adat, Suku Bangsa, Bangsa, dan Negara ditinjau dari Perspektif Hak Asasi Manusia, Jakarta: Komnas HAM.

Mary, S. Rahma H. dan Noer Fauzi Rachman, 2011, Mesuji: Cermin Konflik Agraria yang Kronis, Bogor: Konsorsium Pembaruan Agraria. 